\title{
Effect of Deficit Irrigation on Soybean (Glycine max L.) Under Conventional, Fixed and Alternate Furrow Irrigation Systems at Jimma, Ethiopia
}

\author{
Robel Admasu* Addisu Asefa Minda Tadesse \\ Jimma Agricultural Research Center P. Box 192, Jimma, Ethiopia
}

\begin{abstract}
Irrigation water supplies are decreasing in many areas of the Ethiopian regions, which is requiring many farmers to consider deficit-irrigating soybean (Glycine max L.). This study investigated the response of soybean (Glycine max L.) to moisture deficit under conventional, alternate and fixed furrow irrigation system over a three years period. A field experiment was conducted at Jimma Agricultural Research. A randomized complete block design (RCBD) with three replications was used. nine treatments which combined and imposed at all growth stages were used. The three years combined result indicated that there were a highly significant $(\mathrm{P}<0.01)$ variation among treatments for grain yield, above ground dry biomass yield and water productivity. The grain yield of soybean was significantly $(\mathrm{P}<0.01)$ affected due to moisture stress imposed at different growth stages. Accordingly, the highest grain yield was obtained from conventional furrow $100 \%$ ETc irrigating all growth stage treatment followed by conventional furrow $75 \%$ ETc and alternate furrow $100 \%$ ETc. The highest water productivity of $1.23 \mathrm{~kg} \mathrm{~m}-3$ was obtained from alternate irrigation system at 50 ETc but the yield loss is not tolerable. Alternate furrow 100\% ETc and conventional furrow 50\% ETc gave a better yield with high water productivity. Therefore, for better water productivity without a significant yield loss, it is recommended to use alternate furrow irrigation with $100 \%$ ETc and conventional furrow irrigation $50 \%$ ETc. In addition, if the water resource is not scarce in the area, it is recommended to use conventional furrow irrigation with $100 \%$ ETc throughout the whole growth stage to obtain optimum yield.
\end{abstract}

Keywords: Water productivity, Deficit irrigation, ETc, Furrow irrigation system, Soybean

DOI: $10.7176 / \mathrm{JBAH} / 9-2-01$

\section{Introduction}

Water is one of the basic natural resources for humanity, but it is often scarce. Mainly spatial and temporal variability in rainfall aggravate water scarcity problem. The ever-increasing world population and the demand for additional water supply by industrial, municipal and agricultural sectors exert a lot of pressure on renewable water resources (Valipour, 2014). it is a main limiting factor for restricting crop production in the world (Umar, 2006). Irrigated agriculture is the main solution to produce crop to feed and achieve the different needs for an ever-increasing world population. However, a Growing competition for water from domestic and industrial sectors reduced its availability for irrigation. In this regards irrigation only based on crop water requirement is not an option especially in areas where water resource is limited.

Many investigations have been conducted to gain experiences in irrigation of crops to maximize performances, efficiency and profitability. However, investigations in water saving irrigation still are continued (Sleper et al., 2007). A recent innovative approach to save agricultural water is deficit irrigation. Deficit irrigation provides a means of reducing water consumption while minimizing adverse effects on yield (Mermoud et al., 2005). Deficit irrigation consists of finding the optimum balance between water use and crop yield. Under deficit irrigation, crop producers allow the crop to experience some water stress, but the water saved should allow an increase in the area irrigated, or it could be put to more productive use. ICARDA has shown that a 50\% reduction in irrigation water applied decreased yields by 10 to $15 \%$, and overall farm productivity increased by $38 \%$ when the water saved was used on other land (Pereira et al., 2002).

Soybean (Glycine max L.) is the world's most important grain legume crop in terms of total production, consumption and international trade. It is an important grain legume because of its high protein (35\%), and nitrogen fixing ability (17-127 kg N ha ${ }^{-1}$ year $^{-1}$ ) (Messina, 1997). Soybean is inherently more stress tolerant (Singh et al., 2003) than other legume crops but it still suffers considerable damage due to drought stresses in different regions.

The response of soybean and other legumes to water deficits has been analyzed by various workers who often have documented reduced yields of these crop as a result of moisture stress (Muirhead and White, 1981; Karamanos, 1984; Villalobos-Rodriguez et al., 1984). Payero et al., (2008) reported that water deficit can affect growth, development and physiological processes of maize plants, which reduce biomass yield. However, there is a gap on water productivity enhancement and the critical moisture deficit level for optimal production which can help to face the challenge occurs due to water scarcity.

Therefore, determination of the effect of deficit irrigation on water productivity is important to utilize the 
limited water resource without significantly affecting irrigated crop yield. Considering the scarcity of irrigation water, this research was aimed to determine the effect of moisture deficit on water productivity of irrigated soybean.

\section{Materials and Methods}

\section{Description of the experimental area}

The experiment was conducted at Jimma Agricultural research center in south west Ethiopia for the consecutive three years. The Jimma Agricultural research center is located at $7^{0} 46^{\prime} \mathrm{N}$ latitude, $36^{0} 0^{\prime} \mathrm{E}$ longitude, and at an altitude of $1753 \mathrm{~m}$ above sea level. The center receives an average annual rainfall of about $1530 \mathrm{~mm}$ with monthly mean maximum and minimum temperatures of $25.9^{\circ} \mathrm{C}$ and $11.3^{\circ} \mathrm{C}$, respectively. The soil texture has been classified as sandy loam soil and the available water holding capacity per unit meter of the soil profile in the root zone is $121 \mathrm{~mm}$.

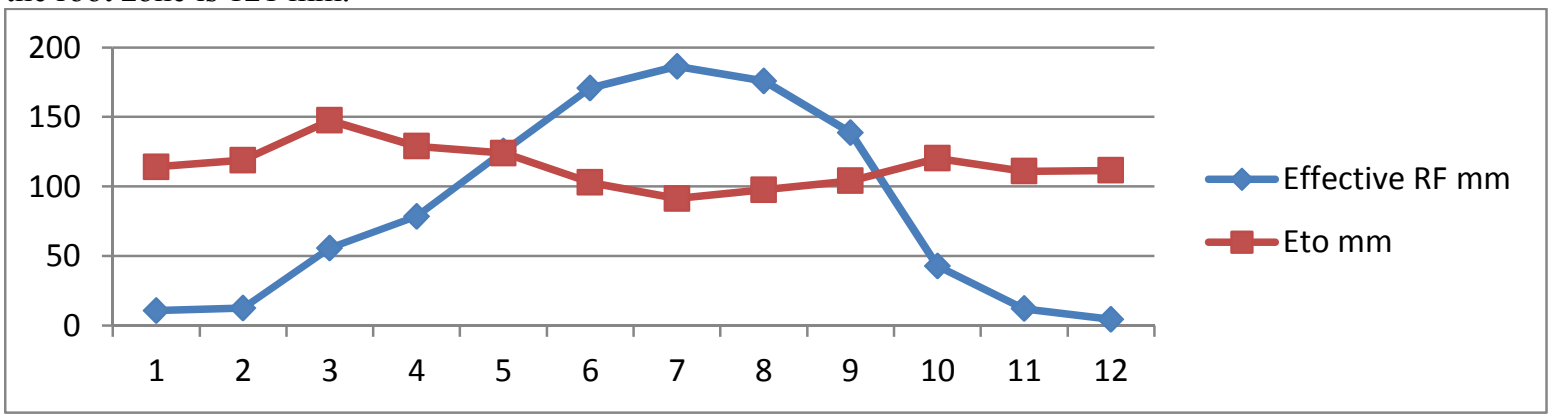

Figure 1. Monthly rainfall as compared with reference evapo-transpiration

\section{Experimental materials, design and management}

A field experiment was carried out in three seasons of 2016 and 2018. Randomized Complete Block Design (RCBD) with three replications was used following the procedure of Gomez and Gomez (1984). Nine treatments of different deficit irrigation level were factorially combined and randomized in plots as shown in Table 1 . The optimal irrigation schedule (ETc) was computed with Cropwat model.

Table 1 - Experimental treatments combinations

\begin{tabular}{|l|l|}
\hline Number & Treatments \\
\hline 1 & Alternate furrow $100 \%$ ETc \\
\hline 2 & Alternate furrow $75 \%$ ETc \\
\hline 3 & Alternate furrow $50 \%$ ETc \\
\hline 4 & Fixed furrow $100 \%$ ETc \\
\hline 5 & Fixed furrow $75 \%$ ETc \\
\hline 6 & Fixed furrow $50 \%$ ETc \\
\hline 7 & Conventional furrow $100 \%$ ETc (Check) \\
\hline 8 & Conventional furrow $75 \%$ ETc \\
\hline 9 & Conventional furrow $50 \%$ ETc \\
\hline
\end{tabular}

Each individual plot had area of $3.0 \mathrm{~m} \mathrm{X} 3.0 \mathrm{~m}=9.0 \mathrm{~m}^{2}$, which consists of 5 rows. Clark $63 \mathrm{~K}$ soybean variety (Glycine $\max$ L.) was used as seed source. The recommended spacing of 75 and $5 \mathrm{~cm}$ between row and plant was employed. Each experimental treatment was fertilized with recommended fertilizer application, that was $100 \mathrm{~kg} / \mathrm{ha}$ and $100 \mathrm{~kg} / \mathrm{ha}$ of DAP and Urea, respectively. All cultural practices were done to all treatments in accordance to the recommendation made for the area. Irrigation water was applied as per the treatment to refill the crop root zone depth close to field capacity.

\section{Data collected}

Yield and growth parameter were recorded and the treatments were compared based on grain yield and growth parameter, which includes plant height, above ground biomass and grain yield. Also, water productivity of the crop was estimated.

Grain yield was calculated by harvesting the total number of plants in the net plot $\left(3.75 \mathrm{~m}^{2}\right)$ and grain yield per plot was measured using electronic balance and then adjusted to $10.0 \%$ moisture and converted to hectare basis. Above ground biomass was determined by harvesting all the plants from the net plot area at physiological maturity and weighed after sun drying to a constant weight and converted to hectare basis. The water productivity was calculated by the ratio of harvested yield per total water used.

$W p=\frac{\text { Harvested grain yield }}{\text { Total water used }}$ 
The data were statistically analyzed combined for all years by SAS software. SAS software version 9.2 for windows was used for analysis (SAS Institute, 1996). Whenever the treatment effects were found significant, GLM test at 1 and 5\% was performed to assess significant difference among treatments means.

\section{Economic evaluation}

To assess the costs and benefits associated with different treatments the partial budget technique as described by CIMMYT (1988) was applied on the yield results. Economic analysis was done using the prevailing market prices during experimentation and at the time the crop was harvested. All costs and benefits were calculated on hectare basis in Ethiopian Birr (ETB/ha). The different costs of the experiment that includes cost for irrigation water and labor cost to irrigate were the variable costs among the different treatments. The adjusted yield was obtained by reducing the average yield by $10 \%$ as indicated in CIMMYT (1988). The average cost the local people were paying for daily labor was 26.00 Birr per day. The farm gate price of Soybean during the harvesting time was 15 Birr $/ \mathrm{kg}$ and the price of irrigation water was taken 1.00 Birr per $10 \mathrm{~m}^{3}$ of water (own assumption). Some of the concepts used in the partial budget analysis are gross benefit, total variable cost and net benefit. The gross benefit was obtained as the product of the real price and the adjusted grain yield of common bean for each treatment. The Dominant analysis procedure as detailed in CIMMYT (1998) was used to select potentially profitable treatments from the range that was tested. The selected and discarded treatments using this technique are referred to as undominated and dominated treatments, respectively. The undominated treatments were ranked from the lowest to the highest variable cost. For each pair of ranked treatments, a percentage marginal rate of return (MRR) was estimated.

\section{Result and Discussion \\ Plant height}

The statistical analysis showed that different deficit irrigation levels had no a significant effect on plant height (Table 2). Even though, the plant height decreased as a soil moisture content in the root zone decreased. Also, the plant height shows a decreasing trend for the different furrow irrigation system. The maximum plant height was obtained from conventional furrow irrigation method followed by alternate furrow and fixed furrow irrigation methods (Figure 2, 3 and 4). Rosadi et al., (2005) revealed that a small level difference in moisture deficit levels did not affect plant height, whereas, it affects when the moisture deficit levels was so high. Abiot (2018) stated that plant height is not statistically different for 100, 75 and 50\% of ETc for Bulga-70 common bean cultivar which agree with current findings.

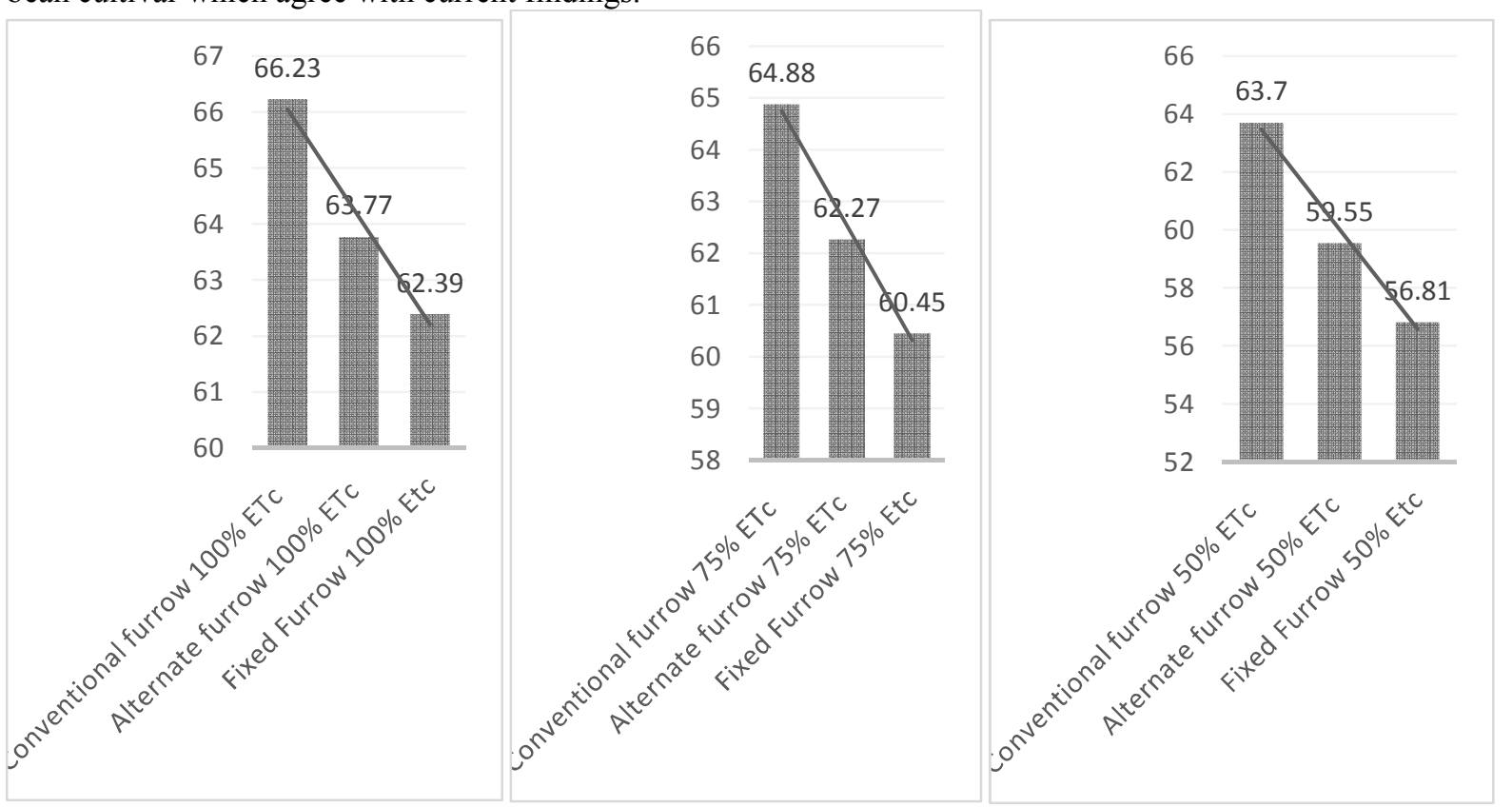

Figure 2- plant height response to conventional, alternate and fixed furrow $100 \% \mathrm{ETc}$
Figure 3- plant height response to conventional, alternate and fixed furrow $75 \% \mathrm{ETc}$
Figure 4- plant height response to conventional, alternate and fixed furrow $50 \%$ ETc 


\section{Above ground dry bio-mass}

Different deficit levels and furrow application method has a significant influence $(p<0.01)$ on dry above ground biomass yield. The mean dry biomass at different deficit level showed decreasing trend due to decreasing of irrigation water applied. From table 2, the maximum above ground dry biomass was obtained from conventional furrow $100 \%$ ETc followed by conventional furrow $75 \%$ ETc, conventional furrow $50 \%$ ETc and alternate furrow $100 \%$ ETc which are statistically not different to each other. Whereas, the minimum was obtained from fixed furrow 50\% ETc followed by fixed furrow 75\% ETc (Table 2). From the present study the trend of dry above ground biomass production fairly decreasing as the amount of water applied decreases. This is due to higher biomass production for well irrigated plots since irrigation was applied based on crop water requirement and moisture stress is reduced. Similar results were reported in the study by Karam et al., (2005). They reported that the applied irrigation water amount reduced dry matter accumulation also reduced. In addition, the furrow irrigation methods showed a significant difference on above ground dry biomass. Conventional furrow irrigation system is a superior one followed by alternate furrow irrigation and fixed furrow irrigation (Table 2). Mulugeta Mohammed and Kannan Narayanan (2015) and Meskelu et al., (2018) revealed that maize above ground dry biomass is higher for conventional furrow irrigation system than alternate and fixed furrow irrigation system.

\section{Grain yield}

The three years over year analysis of soybean grain yield shows a highly significant difference $(\mathrm{P}<0.01)$ on the use of different furrow system as well as on different deficit levels of irrigation. The result revealed that conventional furrow 100\% ETc gave the highest grain yield (1901.8 K.g ha $\left.{ }^{-1}\right)$ followed by conventional furrow $75 \%$ ETc $\left(1769.9 \mathrm{~K}_{\mathrm{g} \mathrm{ha}}{ }^{-1}\right)$ and alternate furrow $100 \%$ ETc $\left(1722.3 \mathrm{~K}_{\mathrm{g} \mathrm{ha}}{ }^{-1}\right)$ (Table 2). The minimum grain yield was obtained from fixed furrow 50\% ETc $\left(1323.1 \mathrm{~K}_{\mathrm{g} \mathrm{ha}}{ }^{-1}\right)$ followed by alternate furrow 50\% ETc $(1445.0$

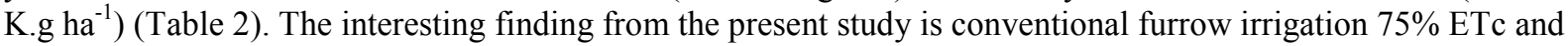
alternate furrow irrigation $100 \%$ ETc showed a minimum yield loss i.e. $7 \%$ and $9 \%$, respectively, over the control treatment. The result indicated the irrigation water applied to the highest yielding treatment next to the control was 25 and $50 \%$ less than that of applied to the control. Different researches conducted on maize (Jonghan Ko and Giovanni Piccinni, 2009), common bean (Simsek et al., 2011) and onion (J. Enciso et al., 2009) revealed that, as the moisture deficit level increased the production of the crop will declined, which agreed with the current finding. When we compare the method of water application conventional furrow and alternate furrow irrigation do not different statistically but, fixed furrow is statistically different with conventional furrow water application method. The reason why the yield result in alternate furrow irrigation is well performing as compared to conventional furrow irrigation system is probably because of a better application efficiency and physiological response associated with alternate furrow irrigation (Kang, 2000; Zhang et al., 2000) and less evapotranspiration associated with alternate furrow irrigation (Stone et al., 1979). Manal A.El-Nady and Amany M. Abdallh (2013) research work on maize revealed that, the highest grain yield was obtained with conventional furrow irrigation while, the lowest yield was obtained with fixed furrow irrigation which agreed with the current finding.

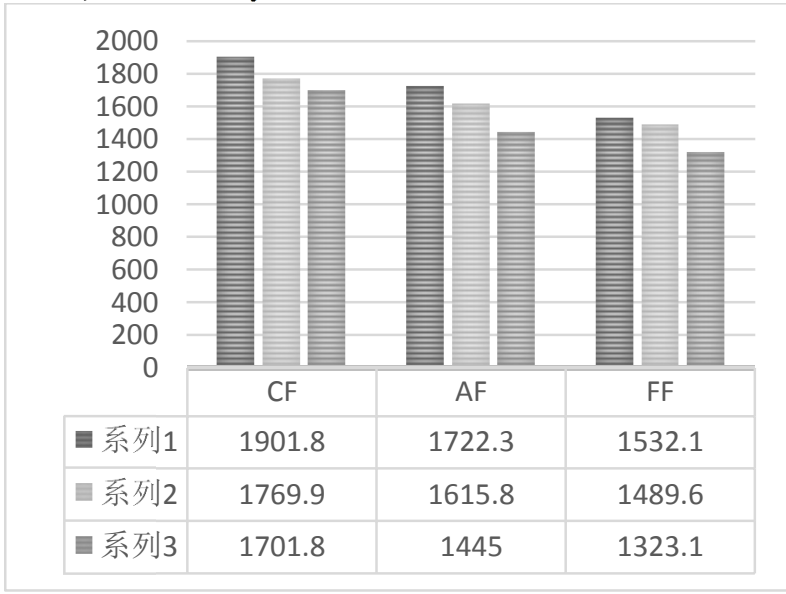

Figure 5- Grain yield response to moisture stress levels

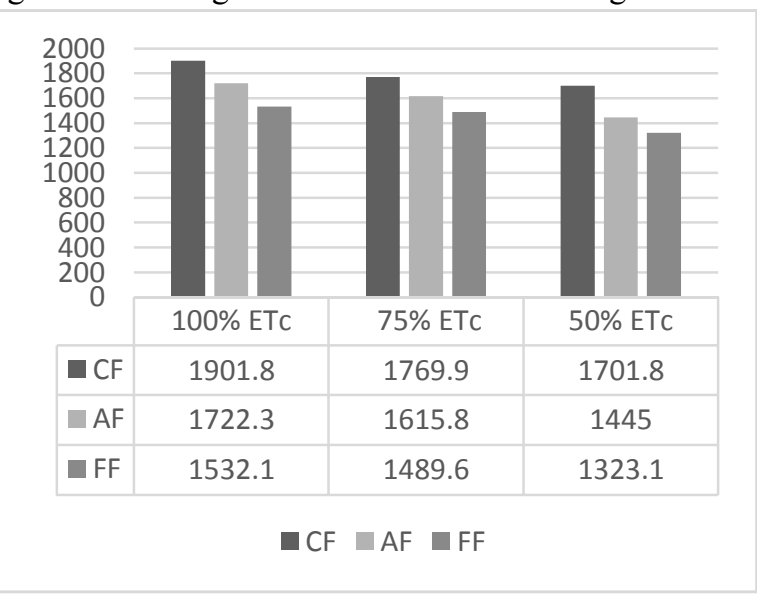

Figure 6- Grain yield response to different furrow irrigation methods

\section{Water productivity}

From the results of analysis of variance (Table 2), there were highly significant difference at $(\mathrm{P}<0.01)$ between the three irrigation systems in water productivity. This is because of the difference in percentage of water actually converted to evapotranspiration out of the total amount applied. This is consistent with the significant improvements in water productivity that have been associated with alternate furrow irrigation (Zhang et al., 
2000). From the table 2, the maximum water productivity obtained from alternate furrow $50 \%$ ETc followed by alternate furrow $75 \%$ ETc. whereas, the minimum was obtained from conventional furrow $100 \%$ ETc. Maximum water productivity obtained from alternate furrow irrigation because of better distribution of the roots in both sides of the ridges and it increases water and fertilizer up take by plants and the physiological response of the crop specifically in the root and leaf parts (Mulugeta Mohammed and Kannan Narayanan, 2015). The trend of water productivity in this experiment agrees with the findings of Yuan et al., (2004) who reported that the trends water productivity for the production of total fresh berry yields. The authors concluded that the lower the amount of irrigation water received, the higher the water productivity obtained for the drier plant biomass and berry yields. Similarly, Sezen et al., (2005) reported that higher water productivity was obtained with lowest irrigation level in field grown beans. However, lower irrigation level resulted in lower total yield. Yalew (2007) investigated that although yield increment is generally accompanied with an increase in the total water use, higher WP was recorded with the deficit application.

Table 2. Effect of deficit and furrow irrigation systems on yield and water productivity

\begin{tabular}{|c|c|c|c|c|}
\hline Treatments & $\begin{array}{l}\text { Plant } \\
\text { Height } \\
(\mathrm{cm})\end{array}$ & $\begin{array}{c}\text { Dry Bio-mass } \\
\text { Yield** } \\
\left(\mathrm{t} \mathrm{ha}^{-1}\right)\end{array}$ & 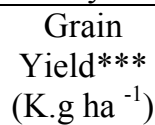 & $\begin{array}{c}\text { Water } \\
\text { Productivity*** } \\
\left({\left.\mathrm{K} . \mathrm{gha}^{-1}\right)}^{*{ }^{-1}}\right.\end{array}$ \\
\hline Alternate furrow $100 \% \mathrm{ETc}$ & 63.77 & $5.88^{\mathrm{a}-\mathrm{c}}$ & $1722.3^{\mathrm{ab}}$ & $0.97^{\mathrm{bc}}$ \\
\hline Alternate furrow $75 \% \mathrm{ETc}$ & 62.27 & $5.67^{\mathrm{bc}}$ & $1615.8^{\mathrm{bc}}$ & $1.15^{\mathrm{b}}$ \\
\hline Alternate furrow $50 \% \mathrm{ETc}$ & 59.55 & $5.64^{\mathrm{bc}}$ & $1445.0^{\mathrm{c}}$ & $1.24^{\mathrm{a}}$ \\
\hline Fixed furrow $100 \%$ ETc & 62.39 & $5.44^{\mathrm{bc}}$ & $1532.1^{\mathrm{c}}$ & $0.82^{\mathrm{d}}$ \\
\hline Fixed furrow $75 \%$ ETc & 60.45 & $4.98^{\mathrm{bc}}$ & $1489.6^{\mathrm{c}}$ & $0.95^{\mathrm{c}}$ \\
\hline Fixed furrow $50 \%$ ETc & 56.81 & $4.83^{c}$ & $1323.1^{\mathrm{cd}}$ & $1.04^{\mathrm{b}}$ \\
\hline Conventional furrow $100 \%$ ETc & 66.23 & $6.79^{\mathrm{a}}$ & $1901.8^{\mathrm{a}}$ & $0.57^{\mathrm{f}}$ \\
\hline Conventional furrow $75 \%$ ETc & 64.88 & $6.33^{\mathrm{ab}}$ & $1769.9^{\mathrm{ab}}$ & $0.68 \mathrm{e}$ \\
\hline Conventional furrow $50 \%$ ETc & 63.70 & $5.98^{\mathrm{ab}}$ & $1701.8^{\mathrm{ab}}$ & $0.95^{\mathrm{c}}$ \\
\hline LSD at 0.01 & ns & 1.05 & 242.04 & 0.08 \\
\hline $\mathrm{CV} \%$ & 10.9 & 16.5 & 15.6 & 8.8 \\
\hline
\end{tabular}

Means with the same column followed by the same letters are not significantly different. *significant $(\mathrm{p}<0.05)$, $* *$ significant $(\mathrm{p}<0.01),{ }^{*} * *_{\text {significant }(\mathrm{p}<0.001)}{ }^{\text {ns }}$ not significant $(\mathrm{p}<0.05)$.

\section{Economic comparison of stage specific moisture stress}

The results of economic analysis revealed that, the highest net benefit of 25,838.6 and 25154.0 ETB/ha obtained from alternate furrow irrigation with $100 \%$ ETc and $75 \%$ ETc, respectively with a marginal rate of return (MRR) of 56.4 and $150.9 \%$. Data in Table 3 showed that, the MRR at alternate furrow irrigation with $100 \%$ ETc and $50 \%$ ETc was greater than 50\% MRR showed an economically feasible. Sensitivity analysis of irrigation method relative to $10 \%$ increase in the cost of water and labor as well as $10 \%$ loss due to different post-harvest problem, transportation and storage the MRR remains above the acceptable range. This depict relative advantage and stability of economic benefits due to the irrigation method in the production of Soybean in Jimma and other similar area. 
Table 3- Economic analysis of Soybean grain yield production under different furrow irrigation methods and irrigation water amount

\begin{tabular}{|c|c|c|c|c|c|c|c|c|}
\hline Treatments & $\begin{array}{c}\text { Mean } \\
\text { Yield } \\
\text { (K.g/ha) }\end{array}$ & $\begin{array}{c}\text { Adjusted } \\
\text { Yield } \\
\text { (K.g/ha) } \\
\end{array}$ & $\begin{array}{c}\text { Gross } \\
\text { Benefit } \\
(\mathrm{ETB} / \mathrm{ha}) \\
\end{array}$ & $\begin{array}{c}\text { Cost of } \\
\text { Irrigation Water } \\
(\mathrm{ETB} / \mathrm{ha})\end{array}$ & $\begin{array}{c}\text { Labor } \\
\text { Cost } \\
(\mathrm{ETB} / \mathrm{ha}) \\
\end{array}$ & $\begin{array}{c}\text { Gross } \\
\text { Cost } \\
(\mathrm{ETB} / \mathrm{ha}) \\
\end{array}$ & $\begin{array}{c}\text { Net } \\
\text { Benefit } \\
(\mathrm{ETB} / \mathrm{ha}) \\
\end{array}$ & $\begin{array}{c}\text { MRR } \\
(\%)\end{array}$ \\
\hline $\begin{array}{l}\text { CF } 100 \% \\
\text { ETc }\end{array}$ & 2092.0 & 1882.78 & 33890.08 & 693.3 & 9993.8 & 10687.1 & 23203.0 & $\mathrm{D}$ \\
\hline $\begin{array}{ll}\mathrm{CF} & 75 \% \\
\mathrm{ETc} & \\
\end{array}$ & 1946.9 & 1752.20 & 31539.62 & 522.2 & 7495.3 & 8017.5 & 23522.1 & $\mathrm{D}$ \\
\hline $\begin{array}{ll}\text { CF } & 50 \% \\
\text { ETc } & \\
\end{array}$ & 1872.0 & 1684.78 & 30326.08 & 355.6 & 4996.9 & 5352.4 & 24973.7 & $\mathrm{D}$ \\
\hline $\begin{array}{ll}\text { AF } & 100 \% \\
\text { ETc } & \end{array}$ & 1894.5 & 1705.07 & 30691.39 & 355.6 & 4497.2 & 4852.7 & 25838.6 & 56.4 \\
\hline $\begin{array}{ll}\text { AF } & 75 \% \\
\text { ETc } & \end{array}$ & 1777.4 & 1599.64 & 28793.56 & 266.7 & 3372.9 & 3639.6 & 25154.0 & 150.9 \\
\hline $\begin{array}{ll}\text { AF } & 50 \% \\
\text { ETc } & \end{array}$ & 1589.5 & 1430.55 & 25749.9 & 177.8 & 2248.6 & 2426.4 & 23323.5 & 838.1 \\
\hline $\begin{array}{l}\text { FF } 100 \% \\
\text { ETc }\end{array}$ & 1685.3 & 1516.77 & 27302.02 & 355.6 & 4034.1 & 4389.6 & 22912.4 & $\mathrm{D}$ \\
\hline $\begin{array}{ll}\text { FF } & 75 \% \\
\text { ETc } & \\
\end{array}$ & 1638.6 & 1474.70 & 26544.67 & 266.7 & 3025.5 & 3292.2 & 23252.5 & $\mathrm{D}$ \\
\hline $\begin{array}{ll}\text { FF } & 50 \% \\
\text { ETc } & \\
\end{array}$ & 1455.4 & 1309.86 & 23577.64 & 177.8 & 2017.0 & 2194.8 & 21382.8 & $\mathrm{D}$ \\
\hline \multicolumn{9}{|c|}{ Sensitivity Analysis } \\
\hline Treatments & $\begin{array}{c}\text { Mean } \\
\text { Yield } \\
\text { (K.g/ha) }\end{array}$ & $\begin{array}{l}\text { Adjusted } \\
\text { Yield } \\
\text { (K.g/ha) }\end{array}$ & $\begin{array}{c}\text { Gross } \\
\text { Benefit } \\
(\mathrm{ETB} / \mathrm{ha})\end{array}$ & $\begin{array}{c}\text { Cost of } \\
\text { Irrigation Water } \\
(\mathrm{ETB} / \mathrm{ha})\end{array}$ & $\begin{array}{c}\text { Labor } \\
\text { Cost } \\
(\mathrm{ETB} / \mathrm{ha})\end{array}$ & $\begin{array}{c}\text { Gross } \\
\text { Cost } \\
(+10 \%) \\
(\text { ETB } / \mathrm{ha})\end{array}$ & $\begin{array}{c}\text { Net } \\
\text { Benefit } \\
(-10 \%) \\
(\text { ETB/ha) }\end{array}$ & $\begin{array}{c}\text { MRR } \\
(\%)\end{array}$ \\
\hline $\begin{array}{ll}\text { CF } & 100 \% \\
\text { ETc } & \end{array}$ & 2092.0 & 1882.78 & 33890.08 & 693.3 & 9993.8 & 11755.79 & 20882.70 & $\mathrm{D}$ \\
\hline $\begin{array}{ll}\text { CF } & 75 \% \\
\text { ETc } & \\
\end{array}$ & 1946.9 & 1752.20 & 31539.62 & 522.2 & 7495.3 & 8819.286 & 21169.88 & $\mathrm{D}$ \\
\hline $\begin{array}{ll}\mathrm{CF} & 50 \% \\
\mathrm{ETc} & \\
\end{array}$ & 1872.0 & 1684.78 & 30326.08 & 355.6 & 4996.9 & 5887.668 & 22476.29 & $\mathrm{D}$ \\
\hline $\begin{array}{ll}\mathrm{AF} & 100 \% \\
\mathrm{ETc} & \end{array}$ & 1894.5 & 1705.07 & 30691.39 & 355.6 & 4497.2 & 5338.011 & 23254.78 & 50.79 \\
\hline $\begin{array}{ll}\text { AF } & 75 \% \\
\text { ETc } & \end{array}$ & 1777.4 & 1599.64 & 28793.56 & 266.7 & 3372.9 & 4003.508 & 22638.6 & 135.79 \\
\hline $\begin{array}{ll}\mathrm{AF} & 50 \% \\
\mathrm{ETc} & \\
\end{array}$ & 1589.5 & 1430.55 & 25749.9 & 177.8 & 2248.6 & 2669.006 & 20991.18 & 685.70 \\
\hline $\begin{array}{ll}\text { FF } & 100 \% \\
\text { ETc } & \\
\end{array}$ & 1685.3 & 1516.77 & 27302.02 & 355.6 & 4034.1 & 4828.574 & 20621.17 & $\mathrm{D}$ \\
\hline $\begin{array}{ll}\text { FF } & 75 \% \\
\text { ETc } & \\
\end{array}$ & 1638.6 & 1474.70 & 26544.67 & 266.7 & 3025.5 & 3621.43 & 20927.22 & $\mathrm{D}$ \\
\hline $\begin{array}{ll}\text { FF } & 50 \% \\
\text { ETc } & \end{array}$ & 1455.4 & 1309.86 & 23577.64 & 177.8 & 2017.0 & 2414.287 & 19244.55 & $\mathrm{D}$ \\
\hline
\end{tabular}

Remarks CF - Conventional furrow, AF-Alternate furrow, FF- Fixed furrow, ETc-crop water requirement (Evapotranspiration of the crop)

\section{Conclusion and Recommendation}

Improving irrigation water management for crop production is becoming important as the water supplies shrink and competition with urban centers in the region grows. In this study, grain yield responses under furrow irrigation methods and deficit irrigations levels based on crop ETc and water productivity were described: the grain yields were increased as irrigation increased. There were significant differences in in grain yield as an applied irrigation water reduced from $100 \%$ to $50 \%$ ETc for conventional, alternate and furrow irrigation methods. In the case of different furrow irrigation methods, conventional furrow and alternate furrow irrigation methods produce significantly different grain yield when compared with fixed furrow irrigation. The maximum was obtained from conventional furrow followed by alternate furrow. Even though, in the case of water 
productivity, alternate furrow irrigation produces significantly higher water productivity than conventional furrow. Alternate furrow irrigation method helps to save $50 \%$ of the total water applied on conventional furrow irrigation. Also, it was observed that, the water productivity increased as the irrigation water amount decreased. The results demonstrate that deficit irrigation in soybean is possible and shows the clear advantage of alternate furrow irrigation over conventional furrow irrigation system. Though fixed furrow irrigation system had high water use efficiency the loss in yield for the correspondent level of deficit was much higher than that of the alternative furrow irrigation. The economic analysis revealed that application of water by using alternate furrow irrigation method at $100 \%$ and $75 \%$ ETc gave maximum net benefit with highest MRR. Therefore, for better water productivity without a significant yield loss and best economic return, it is recommended to use alternate furrow irrigation with $100 \%$ ETc and alternate furrow irrigation $75 \% \mathrm{ETc}$.

\section{Acknowledgment}

The Authors are thankful to staff of Jimma Agricultural Research Center in general for providing necessary support to conduct the study. Our special thanks also go to Ethiopian Institute of Agricultural Research (EIAR) for financial support to conduct the study in particular, researcher as well as technicians in the natural resource directorate.

\section{References}

Abiot Molla (2018). The Effect of Soil Moisture Level on Growing of Two Common Bean (Phaseolus Vulgaris L) Cultivars. Mod App Ocean and Petr Sci 1(2)- 2018. MAOPS.MS.ID.000108.

CIMMYT (1988) from Agronomic data to farmer recommendations: An economics training manual. Completely revised edition, Mexico, DF.

Enciso J., B. Wiedenfeld, J. Jifon, and S. Nelson (2009). Onion yield and quality response to two irrigation scheduling strategies. ELSEVER Scientia Horticulturae 120 (2009) 301-305

Jonghan K. and G. Piccinni (2009). Corn yield responses under crop evapotranspiration-based irrigation management. ELSEVER agricultural water management 96 (2009)799-808

Kang S., Z. Lianga, Y. Panb, P. Shic and J. Zhangd (2000). Alternate furrow irrigation for maize production in an arid area. Agricultural Water Management, 45:267-274.

Karam F., R. Masaad, T. Sfeir, O. Mounzer and Y. Rouphael (2005). Evapotranspiration and seed yield of field grown soybean under deficit irrigation conditions. Agric. Water Manag. 2005, 75, 226-244.

Karamanos, A.J. 1984. Effects of water stress on some growth parameters and yield of fieldbean crop. In: P.D. Hebblethwaite, T.C.K. Dawkins, M.C. Heath and G. Lockwood (Editors), Vicia faba: Agronomy, Physiology, and Breeding. World Crops: Production, Utilization, Description. Vol. 10. Martinus Nijhoff/Dr. W. Junk Publishers, The Hague, Netherlands, pp.47-59.

Manal A.E.N. and A.M. Abdallh (2005). Corn Yield Response to some Irrigation Methods and Fertilization with Macro and Micronutrients. Egypt. J. Soil Sci. Vol. 53, No.3, pp. 347-360 (2013)

Mermoud, A., T.D. Tamini, H. Yacouba. (2005). Impacts of different irrigation schedules on the water balance components of an onion crop in a semi-arid zone. Agricultural Water Management 77(1-3): 282-293.

Meskelu E, Tesfaye H, Debebe A and Mohammed M (2018). Integrated Effect of Mulching and Furrow Methods on Maize Yield and Water Productivity at Koka, Ethiopia. Irrigat Drainage Sys Eng 7: 207. doi: 10.4172/2168-9768.1000207

Messina, M. 1997. Soy foods: Their role in disease prevention and treatment. In Liu, K. (ed). Soybeans: Chemistry, Technology and Utilization. Chapman and Hall, New York, Pp. 442-466.

Mohammed M. and N. Kannan (2015). Effect of Deficit Irrigation on Maize under Conventional, Fixed and Alternate Furrow Irrigation Systems at Melkassa, Ethiopia. International Journal of Engineering Research \& Technology (IJERT)

Muiehead, W.A. and R.J.G. White. 1981. The influence of soil water potential on the flowering pattern, pod set and yields of snap beans (Phaeolus vulgaris L.). Irrig. Sci., 3: 45-56.

Payero, J.O., D.D. Tarkalson, S. Irmak, D. Davison and J.L. Petersen (2008). Effect of irrigation amounts applied with subsurface drip irrigation on corn evapotranspiration, yield, water use efficiency, and dry matter production in a semiarid climate. Agric. Water Manage. 95: 895-908.

Pereira, L.S., T. Oweis, A. Zairi. 2002. Irrigation Management under Water Scarcity. AgriculturalWater Management, 57: 175-206.

Rosadi R A B, M.S. Afandi, M. Senge, K. Ito and J.T. Adomako (2005). Critical water content and water stress coeffcient of soybean (Glycine max [L.] Merr.) under defcit irrigation. Paddy and Water Environment 3: 219-223

Sezen, S.M., A. Yazar, M. Canbolat, S. Eker and G. Celikel, 2005. Effect of drip irrigation Management on yield and quality of field grown beans. Agri. Water Manage. 71(2005) (3): 243-255.

Simsek M., N. Comlekcioglu and I. Ozturk (2011). The effects of the regulated deficit irrigation on yield and 
some yield components of common bean (Phaseolus vulgaris L.) under semi-arid conditions African Journal of Biotechnology Vol. 10(20), pp. 4057-4064, 16 May, 2011

Singh, B. B., P. Hartmann, C. Fatokun, M. Tamo, S. Tarawali and R. Ortiz. 2003. Recent progress on cowpea improvement. Chron. Hortic. 43: 8-12.

Sleper, D.A., S.L. Fales, and M.E. Collins, 2007.Foreword. In: Irrigation of agricultural crops (R.J. Lascano and R.E. Sojka, eds.), 2nd edition, Agronomy MonograpH no. 30. ASA-CSSA-SSSA publishing, 664p.

Stone, J.F., J.E. Garton, B. B. Reeves and H.E. Keflemariam. 1979. Irrigation water conservation using widespaced furrows. Soil Sci. Am. J., 43: 407-411.

Umar, S. 2006. Alleviating Adverse Effects of Water Stress on Yield of Sorghum, Mustard and Groundnut by Potassium Application. Pak. J. Bot., 38(5): 1373-1380.

Valipour, M. (2014). Pressure on renewable water resources by irrigation to 2060. Acta Advances in Agricultural Sciences 2(8): 23-42.

Villalobos-Rodriguez., E., R. Shibles, and D.E. Green. 1984. Response of stem termination types of soybean to supplemental irrigation. Iowa State J. Res., 59(1): 45-52.

Yalew, Z. (2007). Effect of Deficit Irrigation on the Growth and Yield of Maize (Zea may L.): a case study in West Gojjam Administrative Zone, Amhara National Regional State, Ethiopia. MSc. Thesis. Dryland Agronomy. Mekele University, Mekele.

Yuan, B.Z., J. Sun and S. Nishiyama, 2004. Effect of drip irrigation on strawberry growth and yield inside a plastic green house. Biosystems Engineering 87 (2) (2004): 237- 245.

Zhang, J., S. Kang, Z. Liang., Y. Z. Pan, P. Shi, Y. H. Pan, Z. S. Liang, X. T. Hu. 2000. Soil water distribution, uniformity and water use efficiency under alternate furrow irrigation in arid areas. Irrigation Science 19: $181-190$ 